\title{
INFLUENCE OF VERMICOMPOST AND FYM ON SOIL FERTILITY, RICE PRODUCTIVITY AND ITS NUTRIENT UPTAKE
}

\author{
${ }^{*}$ R. Kamaleshwaran and D. Elayaraja \\ Department of soil science and agricultural chemistry, Faculty of Agriculture, \\ Annamalai University, Chidambaram, Tamil Nadu, India-608002 \\ *Corresponding Author: Ph.D Research Scholar, \\ Research field: Soil science and Agricultural chemistry \\ DOI: https://doi.org/10.51193/IJAER.2021.7402
}

\begin{abstract}
The wide category of organic fertilizers includes different product formulations which provide plant nutrients besides improving the organic matter content of the soil. FYM and Vermicompost are well known cheap organic nutrient sources obtained from agro wastes. The beneficial effects of FYM and vermicompost increase the microbial population and organic carbon content of the soil and promotes better plant growth. This approach tends to be ecofriendly thereby reducing environmental pollution. The present study highlights the formulated effect of vermicompost and FYM on soil nutrient status and nutrient uptake by rice. This study was carried by randomized block design with three replication and eleven treatments, the treatments viz., $\mathrm{T}_{1}-$ Control, $\mathrm{T}_{2-}$ $50 \% \mathrm{RDF}+50 \%(\mathrm{FYM}+\mathrm{VC}), \mathrm{T}_{3}-\mathrm{RDF}+50 \%$ Enriched FYM, $\mathrm{T}_{4}-\mathrm{RDF}+75 \%$ Enriched FYM, $\mathrm{T}_{5}-\mathrm{RDF}+100 \%$ Enriched FYM, T6- RDF+ $125 \%$ Enriched FYM, T $7-$ RDF+ $150 \%$ Enriched FYM, $\mathrm{T}_{8}-\mathrm{RDF}+50 \%$ Enriched $\mathrm{VC}, \mathrm{T}_{9}-\mathrm{RDF}+75 \%$ Enriched VC, $\mathrm{T}_{10}-\mathrm{RDF}+100 \%$ Enriched $\mathrm{VC}, \mathrm{T}_{11}-\mathrm{RDF}+125 \%$ Enriched $\mathrm{VC}, \mathrm{T}_{12}-\mathrm{RDF}+150 \%$ Enriched $\mathrm{VC}$. The results from $\mathrm{T}_{5}$ and $\mathrm{T}_{10}$ indicate that Enriched FYM and Vermicompost with NPK could improve soil fertility, Rice productivity, Nutrient uptake, yields and quality.
\end{abstract}

Keywords: FYM, Vermicompost

\section{INTRODUCTION}

Rice (Oryza sativa L.) is the staple food to feed over half of the world's population. Use of inorganic fertilizers has several negative impacts on soil fertility presently; use of organic sources is slowly mushrooming up over the globe due to its scientifically proven beneficial effects. In India, rice is grown in about 43.86 million hectares with a production level of 104.80 
International Journal of Agriculture and Environmental Research

ISSN: 2455-6939

Volume: 07, Issue: 04 "July-August 2021"

million tones and the productivity is about $2390 \mathrm{~kg} / \mathrm{ha}$ [21]. There is an ample scope to increase the productivity of rice. To increase the productivity of rice, it is important to maintain the fertility and organic matter status of soil. In vermicompost, the secretions from worms and associated microbes act as growth promoters. Since, it is a natural eco-friendly approach; it does not have any adverse impact on the soil or the environment. Certain metabolites produced by the earthworms may also be responsible to stimulate the plant growth. Vermicompost also helps in preventing plant diseases [1]. The nutrients present in vermicompost are readily available [2].A positive effect of vermicompost application on yield attributes and yield of various crops [3][4][5]. Vermicompost helps in improving and protecting fertility of top soil and also helps in boosting up the productivity by $40 \%$ [6]. FYM is a cheap source organic amendment which increases the productivity of rice in a similar manner. The objective of the study highlighted the impact of FYM and vermicompost on soil fertility and nutrient uptake by rice.

\section{MATERIALS AND METHODS}

The present field experiment was conducted in a farmer's field of Sethiathoope, Cuddalore district in Tamilnadu during Kharif 2019. The soil of the experimental site was sandy loam with pH 8.09, Organic carbon content $0.43 \%$, available nitrogen $155.5 \mathrm{~kg} \mathrm{ha}^{-1}$, Phosphorus $13.8 \mathrm{~kg} \mathrm{ha}^{-}$ ${ }^{1}$, Potassium $141.5 \mathrm{~kg} \mathrm{ha}^{-1}$. The experiment was laid out in RBD consisting eleven treatments viz., $\mathrm{T}_{1-}$ Control, $\mathrm{T}_{2}-50 \% \mathrm{RDF}+50 \%(\mathrm{FYM}+\mathrm{VC}), \mathrm{T}_{3}-\mathrm{RDF}+50 \%$ Enriched FYM, $\mathrm{T}_{4}-\mathrm{RDF}+$ $75 \%$ Enriched FYM, $\mathrm{T}_{5^{-}} \mathrm{RDF}+100 \%$ Enriched FYM, $\mathrm{T}_{6}-\mathrm{RDF}+125 \%$ Enriched FYM, $\mathrm{T}_{7^{-}}$ $\mathrm{RDF}+150 \%$ Enriched FYM, $\mathrm{T}_{8-} \mathrm{RDF}+50 \%$ Enriched $\mathrm{VC}, \mathrm{T}_{9}-\mathrm{RDF}+75 \%$ Enriched $\mathrm{VC}, \mathrm{T}_{10^{-}}$ $\mathrm{RDF}+100 \%$ Enriched VC, $\mathrm{T}_{11}-\mathrm{RDF}+125 \%$ Enriched $\mathrm{VC}, \mathrm{T}_{12}-\mathrm{RDF}+150 \%$ Enriched VC. The experimental site was ploughed a day before transplanting and was divided into 33 plots by bunds of 0.5 meters. Individual plot was puddled and leveled manually just before transplanting. Very young seedlings of ADT 38 medium duration rice variety at 2 leaf stage were transplanted on the field (one plant per hill) with a spacing of $(25 \mathrm{~cm} \mathrm{X} 25 \mathrm{~cm})$ for encouraging greater root and canopy growth. Recommended dose of fertilizer 150:50:50 $\mathrm{kg} \mathrm{ha}^{-1}$ was applied at 4 split doses viz., basal, tillering, panicle initiation and heading stages with various levels of FYM and Vermicompost to be followed in both nursery and experimental site. Water management was done by introducing $1-2 \mathrm{~cm}$ layer of water into the field. Hand weeding was done at 30 days after transplanting and 45 days after transplanting to reduce the competition between weeds and crops for nutrients, space, light and moisture. Growth and yield characters were recorded as per standard procedures and using standard formulas.

$$
\text { Nutrient uptake }\left(\mathrm{kg} \mathrm{ha}^{-1}\right)=\quad \text { Nutrient content }(\%) \times \text { dry weight in }\left(\mathrm{kg} \mathrm{ha}^{-1}\right)
$$


International Journal of Agriculture and Environmental Research

ISSN: 2455-6939

Volume: 07, Issue: 04 "July-August 2021"

\section{RESULTS AND DISCUSSION}

The plant height increased rapidly due to the use of organic amendments. Subsequent plant height was slower particularly at 90 days after transplanting (DAT) and harvest stage due to higher photosynthetic demand to meet the nutrient requirement at reproductive stage. The plant height increased with certain level of organic treatments from $T_{1}$ to $T_{12}$. The treatment $T_{10}$ recorded taller plants $\left(96.10 \mathrm{~cm}\right.$ ) which Significantly on par with the treatment $\mathrm{T}_{5} 92.98 \mathrm{~cm}$ (Table 1). The treatment $T_{10}$ was superior over the control at all growth stages till harvest. Superior performance of FYM /GM which might be due to reduced loss of Nitrogen by fixation of $\mathrm{NH}_{4}{ }^{+}$ion with humus present in FYM and increased availability of $\mathrm{N}$ to crop which ultimately increased the plant height [10]. Available Nitrogen, Beneficial microbial population, Enzymes released by microbes in FYM and Vermicompost increases plant growth, yield and nutrient uptake in rice. [7][8][9].

The data on tillers $\mathrm{m}^{-2}$ was recorded at regular intervals (Table 2) which indicated a steady increase in the number of tillers $\mathrm{m}^{-2}$ up to $60 \mathrm{DAT}$, there after declined with the advancement in stages. The reduction in the number of tillers after 60 days may be due to ageing and senescence which are responsible for dying of the secondary and tertiary tillers. The number of tillers increased with increasing level of organics from $T_{1}$ to $T_{12}$. Significantly, more number of tillers $\left(334.23 \mathrm{~m}^{-2}\right.$ ) (Table 2) were recorded in $\mathrm{T}_{10}$ which was on par with the treatment $\mathrm{T}_{5}$ that recorded number of tillers of $328.58 \mathrm{~m}^{-2}$. Tillering is the product of the expansion of auxiliary buds which is closely associated with the nutritional conditions of the culm because a tiller receives carbohydrate and nutrient from the culm during its early growth period which improved by the application of nitrogen [11]. Available Nitrogen, and Enzymes released by microbes in FYM and Vermicompost increases plant growth, yield and nutrient uptake in rice. [7][8][9].

The maximum rice grain yield of (51.79 $\left.\mathrm{q} \mathrm{ha}^{-1}\right)$, straw yield $\left(64.29 \mathrm{q} \mathrm{ha}^{-1}\right)$ and harvest index $(45.25 \%)$ was obtained with $\mathrm{T}_{10}$ which remained at par with treatment $\mathrm{T}_{5}$ (Table 3 ). The higher yield was achieved through application of organics because the grain and straw yield is the final product which depends upon the development of yield components such as effective tillers, panicle length, test weight, total and filled grain panicle ${ }^{-1}$. All the yield attributes and yield were higher with the substitution either with enriched FYM or Vermicompost. Farmyard manure might have supplied the essential minerals and worked as catalyst for efficient use of applied nutrients for increasing the yield attributes [17]. These results were findings with the application of organics increases the yield and yield attributes in rice by various microbial processes. [12][13][14][15]16]

$\mathrm{N}$ uptake by rice at harvest is presented in the (Table 4). The treatments that received enriched VC along with the RDF $\left(\mathrm{T}_{10}\right)$ had maximum NPK uptake of 96.76, 27.90, $24.37 \mathrm{~kg} \mathrm{ha}^{-1}$ 
International Journal of Agriculture and Environmental Research

ISSN: 2455-6939

Volume: 07, Issue: 04 "July-August 2021"

respectively, which was at par with treatments $\mathrm{T}_{5}$ (Table 4). These results were in agreement with the findings of Verma [18] who found that incorporation of FYM significantly increased the Nitrogen uptake of seed and straw. Higher Nitrogen uptake in rice with FYM application over no fertilizer and inorganic fertilizers application [19].

At tillering stage, the available soil NPK status was found to be $110.49,38.76$ and $30.88 \mathrm{~kg} \mathrm{ha}^{-1}$ (Table 5). The NPK availability in soil increased with increasing proportion of organics from $\mathrm{T}_{1}$ to $\mathrm{T}_{12}$. Higher NPK availability $164.74,226.24$ and $157.12 \mathrm{~kg} \mathrm{ha}^{-1}$ was recorded with $\mathrm{T}_{10}$ which was on par with the treatment $T_{5}$. Substantial improvement in soil fertility due to residual effect of vermicompost. [20]

Table 1: Effect FYM and vermicompost on plant height

\begin{tabular}{|l|c|c|c|c|}
\hline \multirow{2}{*}{ Treatments } & \multicolumn{3}{|c|}{ Plant height(cm) } \\
\cline { 2 - 5 } & 30 DAT & 60DAT & 90DAT & 130 days \\
\hline $\mathrm{T}_{1}-$ Control & 27.36 & 31.36 & 39.59 & 42.83 \\
\hline $\mathrm{T}_{2}-50 \% \mathrm{RDF}+50 \%$ (FYM+VC) & 30.29 & 34.96 & 44.48 & 47.78 \\
\hline $\mathrm{T}_{3}-\mathrm{RDF}+50 \%$ Enriched FYM & 33.54 & 38.97 & 49.46 & 52.95 \\
\hline $\mathrm{T}_{4}-\mathrm{RDF}+75 \%$ Enriched FYM & 36.78 & 42.96 & 54.50 & 58.06 \\
\hline $\mathrm{T}_{5}-\mathrm{RDF}+100 \%$ Enriched FYM & 58.46 & 69.55 & 87.97 & 92.98 \\
\hline $\mathrm{T}_{6}-\mathrm{RDF}+125 \%$ Enriched FYM & 39.99 & 46.93 & 59.52 & 63.16 \\
\hline $\mathrm{T}_{7}-\mathrm{RDF}+150 \%$ Enriched FYM & 43.17 & 50.85 & 64.47 & 68.23 \\
\hline $\mathrm{T}_{8}-\mathrm{RDF}+50 \%$ Enriched VC & 46.31 & 54.70 & 69.32 & 73.25 \\
\hline $\mathrm{T}_{9}-\mathrm{RDF}+75 \%$ Enriched VC & 49.41 & 58.52 & 73.91 & 78.24 \\
\hline $\mathrm{T}_{10}-\mathrm{RDF}+100 \%$ Enriched VC & 59.71 & 71.67 & 91.12 & 96.10 \\
\hline $\mathrm{T}_{11}-\mathrm{RDF}+125 \%$ Enriched VC & 55.47 & 65.90 & 83.32 & 88.13 \\
\hline $\mathrm{T}_{12}-\mathrm{RDF}+150 \%$ Enriched VC & 52.45 & 62.23 & 78.63 & 83.21 \\
\hline $\mathrm{S} . \mathrm{Em} \pm$ & 1.62 & 2.79 & 3.78 & 3.85 \\
\hline $\mathrm{CD}(\mathrm{P}=0.05)$ & 2.92 & 3.58 & 4.53 & 4.79 \\
\hline
\end{tabular}

(* FYM - Farm Yard Manure, VC- Vermicompost) 
International Journal of Agriculture and Environmental Research

ISSN: 2455-6939

Volume: 07, Issue: 04 "July-August 2021"

Table 2: Effect FYM and vermicompost on number of tillers $\mathbf{m}^{-2}$

\begin{tabular}{|l|c|c|c|c|}
\hline \multirow{2}{*}{ Treatments } & \multicolumn{3}{l}{} \\
\cline { 2 - 5 } & 30 DAm & 60DAT & 90DAT & Maturity \\
\hline $\mathrm{T}_{1}-$ Control & 102.32 & 139.92 & 142.52 & 116.80 \\
\hline $\mathrm{T}_{2}-50 \% \mathrm{RDF}+50 \%(\mathrm{FYM}+\mathrm{VC})$ & 121.45 & 158.51 & 162.97 & 139.38 \\
\hline $\mathrm{T}_{3}-\mathrm{RDF}+50 \%$ Enriched FYM & 139.66 & 181.46 & 182.93 & 165.63 \\
\hline $\mathrm{T}_{4}-\mathrm{RDF}+75 \%$ Enriched FYM & 156.61 & 202.71 & 203.22 & 184.86 \\
\hline $\mathrm{T}_{5}-\mathrm{RDF}+100 \%$ Enriched FYM & 291.86 & 340.07 & 339.22 & 328.58 \\
\hline $\mathrm{T}_{6}-\mathrm{RDF}+125 \%$ Enriched FYM & 173.84 & 223.73 & 223.07 & 206.11 \\
\hline $\mathrm{T}_{7}-\mathrm{RDF}+150 \%$ Enriched FYM & 192.26 & 243.18 & 243.22 & 228.96 \\
\hline $\mathrm{T}_{8}-\mathrm{RDF}+50 \%$ Enriched VC & 211.78 & 263.43 & 263.23 & 253.61 \\
\hline $\mathrm{T}_{9}-\mathrm{RDF}+75 \%$ Enriched VC & 237.23 & 282.99 & 283.08 & 275.03 \\
\hline $\mathrm{T}_{10}-\mathrm{RDF}+100 \%$ Enriched VC & 300.30 & 348.33 & 344.87 & 334.23 \\
\hline $\mathrm{T}_{11}-\mathrm{RDF}+125 \%$ Enriched VC & 275.34 & 321.82 & 320.87 & 315.97 \\
\hline $\mathrm{T}_{12}-\mathrm{RDF}+150 \%$ Enriched VC & 256.77 & 302.86 & 302.31 & 296.70 \\
\hline $\mathrm{S} . \mathrm{Em} \pm$ & 9.24 & 10.59 & 10.18 & 9.87 \\
\hline $\mathrm{CD}(\mathrm{P}=0.05)$ & 16.37 & 18.01 & 17.87 & 17.02 \\
\hline
\end{tabular}

(* FYM - Farm Yard Manure, VC- Vermicompost)

Table 3: Effect vermicompost and FYM on grain yield, straw yield and harvest index

\begin{tabular}{|c|c|c|c|}
\hline Treatments & Grain Yield $\left(q\right.$ ha $\left.^{-1}\right)$ & Straw yield $\left(\mathbf{q}\right.$ ha $\left.^{-1}\right)$ & $\begin{array}{c}\text { Harvest index } \\
(\%)\end{array}$ \\
\hline $\mathrm{T}_{1}$ - Control & 4.55 & 2.49 & 2.78 \\
\hline $\mathrm{T}_{2}-50 \% \mathrm{RDF}+50 \%(\mathrm{FYM}+\mathrm{VC})$ & 9.40 & 8.87 & 6.77 \\
\hline $\mathrm{T}_{3}-\mathrm{RDF}+50 \%$ Enriched FYM & 14.19 & 15.18 & 10.95 \\
\hline $\mathrm{T}_{4}-\mathrm{RDF}+75 \%$ Enriched FYM & 18.96 & 21.43 & 15.28 \\
\hline $\mathrm{T}_{5}-\mathrm{RDF}+100 \%$ Enriched FYM & 50.55 & 63.11 & 44.20 \\
\hline $\mathrm{T}_{6-} \mathrm{RDF}+125 \%$ Enriched FYM & 23.71 & 27.64 & 19.55 \\
\hline $\mathrm{T}_{7}-\mathrm{RDF}+150 \%$ Enriched FYM & 28.39 & 33.82 & 23.74 \\
\hline $\mathrm{T}_{8}-\mathrm{RDF}+50 \%$ Enriched VC & 32.98 & 39.94 & 27.92 \\
\hline $\mathrm{T}_{9}-\mathrm{RDF}+75 \%$ Enriched VC & 37.46 & 45.96 & 32.07 \\
\hline $\mathrm{T}_{10}-\mathrm{RDF}+100 \%$ Enriched VC & 51.79 & 64.29 & 45.25 \\
\hline $\mathrm{T}_{11}-\mathrm{RDF}+125 \%$ Enriched VC & 46.23 & 57.57 & 40.21 \\
\hline $\mathrm{T}_{12}-\mathrm{RDF}+150 \%$ Enriched VC & 41.87 & 51.95 & 36.19 \\
\hline
\end{tabular}


International Journal of Agriculture and Environmental Research

ISSN: 2455-6939

Volume: 07, Issue: 04 "July-August 2021"

\begin{tabular}{|l|l|l|l|}
\hline $\mathrm{S} . \mathrm{Em} \pm$ & 1.51 & 1.54 & 1.14 \\
\hline $\mathrm{CD}(\mathrm{P}=0.05)$ & 4.22 & 5.14 & 3.96 \\
\hline
\end{tabular}

(* FYM - Farm Yard Manure, VC- Vermicompost)

Table 4: Nutrient uptake by grain

\begin{tabular}{|l|c|c|c|}
\hline \multicolumn{1}{|c|}{ Treatments } & $\mathbf{N}\left(\mathbf{k g ~ h a}^{-\mathbf{1}}\right)$ & $\mathbf{P}\left(\mathbf{k g ~ h a}^{-\mathbf{1}}\right)$ & $\mathbf{K}\left(\mathbf{k g ~ h a}{ }^{-1}\right)$ \\
\hline $\mathrm{T}_{1}-$ Control & 5.03 & 1.61 & 3.90 \\
\hline $\mathrm{T}_{2}-50 \%$ RDF+50\%(FYM+VC) & 13.99 & 3.80 & 5.91 \\
\hline $\mathrm{T}_{3}-\mathrm{RDF}+50 \%$ Enriched FYM & 22.67 & 5.98 & 7.97 \\
\hline $\mathrm{T}_{4}-\mathrm{RDF}+75 \%$ Enriched FYM & 31.24 & 8.10 & 10.02 \\
\hline $\mathrm{T}_{5}-\mathrm{RDF}+100 \%$ Enriched FYM & 94.74 & 27.65 & 23.93 \\
\hline $\mathrm{T}_{6}-\mathrm{RDF}+125 \%$ Enriched FYM & 40.40 & 10.35 & 12.04 \\
\hline $\mathrm{T}_{7}-\mathrm{RDF}+150 \%$ Enriched FYM & 49.75 & 13.45 & 14.03 \\
\hline $\mathrm{T}_{8}-\mathrm{RDF}+50 \%$ Enriched VC & 58.95 & 16.47 & 15.98 \\
\hline $\mathrm{T}_{9}-\mathrm{RDF}+75 \%$ Enriched VC & 68.10 & 19.46 & 17.97 \\
\hline $\mathrm{T}_{10}-\mathrm{RDF}+100 \%$ Enriched VC & 96.76 & 27.90 & 24.37 \\
\hline $\mathrm{T}_{11}-\mathrm{RDF}+125 \%$ Enriched VC & 86.07 & 25.09 & 21.97 \\
\hline $\mathrm{T}_{12}-\mathrm{RDF}+150 \%$ Enriched VC & 77.12 & 22.31 & 19.95 \\
\hline $\mathrm{S} . \mathrm{Em} \pm$ & 2.71 & 0.72 & 0.82 \\
\hline $\mathrm{CD}(\mathrm{P}=0.05)$ & 8.43 & 2.12 & 1.94 \\
\hline
\end{tabular}

(* FYM - Farm Yard Manure, VC- Vermicompost)

Table 5: Effect vermicompost and FYM on available N, P and K status of soil

\begin{tabular}{|c|c|c|c|}
\hline Treatments & $\mathbf{N}\left(\mathbf{k g ~ h a}^{-1}\right)$ & $\mathbf{P}\left(\right.$ kg ha $\left.^{-1}\right)$ & $\mathrm{K}\left(\mathrm{kg} \mathrm{ha}^{-1}\right)$ \\
\hline $\mathrm{T}_{1}$ - Control & 70.75 & 20.10 & 17.84 \\
\hline $\mathrm{T}_{2}-50 \% \mathrm{RDF}+50 \%(\mathrm{FYM}+\mathrm{VC})$ & 80.12 & 22.34 & 19.87 \\
\hline $\mathrm{T}_{3}-\mathrm{RDF}+50 \%$ Enriched FYM & 83.34 & 27.60 & 21.73 \\
\hline $\mathrm{T}_{4}-\mathrm{RDF}+75 \%$ Enriched FYM & 89.21 & 30.23 & 24.81 \\
\hline $\mathrm{T}_{5}-\mathrm{RDF}+100 \%$ Enriched FYM & 92.50 & 34.42 & 26.77 \\
\hline $\mathrm{T}_{6}-\mathrm{RDF}+125 \%$ Enriched FYM & 109.89 & 37.87 & 29.94 \\
\hline $\mathrm{T}_{7}-\mathrm{RDF}+150 \%$ Enriched FYM & 98.56 & 36.12 & 28.20 \\
\hline $\mathrm{T}_{8}-\mathrm{RDF}+50 \%$ Enriched VC & 87.34 & 28.32 & 23.79 \\
\hline $\mathrm{T}_{9}-\mathrm{RDF}+75 \%$ Enriched VC & 95.10 & 32.06 & 25.10 \\
\hline
\end{tabular}


International Journal of Agriculture and Environmental Research

ISSN: 2455-6939

Volume: 07, Issue: 04 "July-August 2021"

\begin{tabular}{|l|c|c|c|}
\hline $\mathrm{T}_{10}-\mathrm{RDF}+100 \%$ Enriched VC & 110.49 & 38.76 & 30.88 \\
\hline $\mathrm{T}_{11}-\mathrm{RDF}+125 \%$ Enriched VC & 103.90 & 35.59 & 27.75 \\
\hline $\mathrm{T}_{12}-\mathrm{RDF}+150 \%$ Enriched VC & 99.01 & 34.43 & 28.92 \\
\hline $\mathrm{S} . \mathrm{Em} \pm$ & 2.82 & 0.96 & 0.65 \\
\hline $\mathrm{CD}(\mathrm{P}=0.05)$ & 9.25 & 3.02 & 2.43 \\
\hline
\end{tabular}

(* FYM - Farm Yard Manure, VC- Vermicompost)

\section{CONCLUSIONS}

To the best of our knowledge, this is the first study to comprehensively evaluate how applying organic fertilizers affects NPK status, growth characteristics, and yield of the medium duration rice variety (ADT 38). Organic fertilizers with total $N \geq 4 \%$ had higher availability of $N$ that was synchronized to the $\mathrm{N}$ demand of the rice crop. $\mathrm{P}$ and $\mathrm{K}$ availability was also high. Overall, we recommend the Vermicompost for getting higher grain yield of rice cultivation. This organic amendment not only effectively fertilizes the rice crop but is also a sustainable way of producing rice. Substituting inorganic fertilizers with organic alternatives would also help protect the environment.

\section{ACKNOWLEDGEMENTS}

We acknowledge the technical staff of the University Farm, Annamalai University for supporting the fieldworks in field experiments. Thanks are also due to G. Kiruthika, and M. Ramya Grant for going through the manuscript and offering valuable suggestions.

\section{REFERENCES}

[1] Rao, K.R., Rao, P.A. and Rao, K.t. 2000. Influence of organic manure and fertilizers on the incidence of groundnut leafminer. Approacrema., Modicella Dev. Annals of Plant Protection Sci. 9(1): 12-15.

[2] Robinson. C. H. Inceson, P. Pierce, T.G. and Rowland, A.P. 1992. Nitrogen mobilization by earthworm in limed peat soils under Piceasitchensis, J. Applied Ecol. 29: 226-237.

[3] Vasanthi, D. and Kumarswamy, K. 2000. Efficacy of vermicompost to improve soil fertility and rice yield. Indian J. Soc. Soil. Sci. 47(2): 268-272.

[4] Das, P.K., Jen, M.K. and Sahoo, K.C. 2002. Effect of integrated application of vermicompost and chemical fertilizer on growth and yield of paddy in red soil of South Eastern Ghat Zone of Orissa. Environ and Ecology. 20(1): 13-15. 
International Journal of Agriculture and Environmental Research

ISSN: 2455-6939

Volume: 07, Issue: 04 "July-August 2021"

[5] Singh, R.K., Athokpam, H.S. and Zaliana, C., Singh, N.G. 2005. Integrated management of Azolla, vermicompost and urea on yield of and nutrient uptake by rice and soil fertility. J. Indian, Soc. Soil. Sci. 53(1): 107-110.

[6] Dussere, C. 1992. On the effect of earthworm on the chemical condition of soil. Landbow J. B. Schwiez. 16:75-78.

[7] Krishna, A. Biradarpatil, N.K. and Channappayoundar, B.B. (2008). Influence of System of Rice Intensification (SRI) cultivation on seed yield and quality. Karnataka J. Agril. Sci. 21 (3): 369-372.

[8] Dutta, M. and Chauhan, B.S. (2010). Effect of nutrient management practice on the performance of upland rice in a newly developed terraced land. Indian Agriculture 54: (1/2): 13-21.

[9] Murthy, R.K. (2012). Productivity and economics of rainfed rice as influenced by integrated nutrient management. Madras Agricultural Journal 99(4/6): 266-270.

[10] Bellakki, M. A., Badnaue, V. P. and Setty, R. A. (1998). Effect of long term integrated nutrient management on some important properties of a Vertisols. Journal of Indian Society of Soil Science46: 176-180.

[11] Tisdale, S. L. and Nelson, W. L. (1975). Soil Fertility and Fertilizers, 3rdEdition. The MacMillan Publ. Co. Inc., New York.

[12] Virdia, H. M. Mehta, H. D. Parmar, V. N. Bafna, A. M. Patel, Z. N. and Gami, R.C. (2010). Intergrated nutrient management in transplanted rice (Oryza sativa L.).Green Farming. 1(3):249-252.

[13] Prakash, H.C., Sunitha, B.P. and Gurumurthy, K.(2010). Effect of INM approach on productivity and economics of rice cultivation (Oryza sativa L.) in Bhadra Command, Karnataka, in relation to soil properties. Mysore Journal of Agricultural Sciences 44(4):786-792.

[14] Kumar, V., Tripathi, H. C. and Mishra, S. K. (2012). Impact of integrated nutrient management on yield, economics and soil fertility in hybrid rice (Oryza sativa) - mustard (Brassica juncea) cropping system. New Agriculturist 23(1):21-26.

[15] Sepehya, S., Subehia, S.K. Rana, S.S. and Negi, S.C. (2012). Effect of integrated nutrient management on rice-wheat yield and soil properties in a north western Himalayan region. Indian Journal of Soil Conservation 40(2): 135-140. 
[16] Das, B., Chakraborty, D., Singh, V.K. Aggarwal, P., Singh, R. Dwivedi, B. S. and Mishra, R. P. (2014). Effects of integrated nutrient management practice on soil aggregate properties, its stability and aggregate-associated carbon content in an intensive rice-wheat system. Soil \& Tillage Research 136:9-18.

[17] Ramakrishna, Y., Subedar, Singh and Parihar, S. S. (2007). Influence of irrigation regime and nitrogen management on productivity, nitrogen uptake and water use by rice (Oryza sativa). Indian Journal of Agronomy 52(3): 102-106.

[18] Verma T S. 1991. Influence of Lantana, Eupatorium and Farm yard manure on paddy crop. Oryza. 28: 177-183.

[19] Hossain A T, Rahman F, Saha P K and Solaiman A R M. 2010. Effects of different aged poultry litter on the yield and nutrient balance in boro rice cultivation. Bangladesh Journal of Agricultural Research 35(3): 497-505.

[20] Aruna, E. and Shaik, M. 2005. Influence of conjunctive use of organic and inorganic source of nutrients in rice (Oryza sativa) on crop growth, yield components, yield and soil fertility in rice sunflower (Helianthus annuus) sequence. Indian Journal of Agronomy. 50 (4): 265-268.

[21] Agricultural Statistics at a glance- 2015, Government of India Ministry of Agriculture \& Farmers Welfare Department of Agriculture, Cooperation \& Farmers Welfare Directorate of Economics and Statistics. 